\title{
Operasi Pembangkit Thermal PLTU Mamuju dengan Metode Iterasi Lambda
}

\author{
Marwan Marwan ${ }^{1)}$, Fadhillah Nur Fajriana ${ }^{2)}$, Naely Muchtar ${ }^{3)}$ \\ 1,2,3 Jurusan Teknik Elektro, Politeknik Negeri Ujung Pandang, \\ email: Marwan@poliupg.ac.id ${ }^{1)}$
}

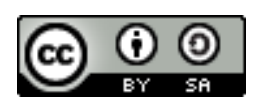

Abstract

Tujuan dari penelitian ini adalah untuk menghitung biaya operasi unit pembangkit listrik tenaga uap (PLTU) yang dioperasikan oleh PT. Rekind Daya Mamuju. Besarnya biaya operasi yang diperlukan untuk membangitkan daya sebesar 2 x 30 MW adalah Rp 483,046,876. Untuk mendapatkan tujuan penelitian, metode itrasi lambda digunakan untuk menghasilkan biaya operasi yang lebih murah. Berdasarkan hasil penelitian menunjukkan bahwa total biaya operasi bahan bakar yang diperlukan adalah sebesar Rp 476,179,149 untuk kedua pembangkit tersebut. Dengan demikian besarnya biaya penghematan yang bisa tercapai dengan penggunaan metode ini sebesar Rp. 6,867,727. Penelitian ini dilakukan pada tanggal 21 Februari 2021.

Keywords: operasi, pembangkit, iterasi, lambda

\section{PENDAHULUAN}

Saat ini, seiring dengan perkembangan tehnologi menyebabkan konsumsi energi listrik semakin meningkat. Hal ini menyebabkan pembangkit energi listrik harus mampu memenuhi permintaan daya konsumen seoptimal mungkin. Disisi lain pemenuhan daya konsumen berakibat meningkatnya biaya operasi pembangkit. Dengan demikian sebuah pembangkit energi listrik dituntut untuk bisa menghasilkan daya yang optimal dengan biaya yang seminimal mungkin.

Menurut [1] salah satu aspek paling penting dalam manajemen sistem tenaga listrik adalah operasi ekonomis pembangkit. Besarnya biaya operasi ekonomis pembangkit sangat ditentukan oleh kapasitas daya yang dibangkitkan dengan kebutuhan energi lisrik konsumen. Untuk mengoptimalkan operasi pembangkit dengan biaya operasi yang murah maka besar beban yang disuplai dan daya yang dihasilkan atau diproduksi oleh pembangkit harus seimbang [2].

Komponen utama dalam sistem ketenaga listrikan yang memerlukan biaya operasi yang besar adalah pembangkit. Menurut [2] sekitar $60 \%$ biaya pengoperasian pembangkit digunakan untuk pengadaan bahan bakar. Dengan demikian pengoptimalan biaya bahan bakar sangat diperlukan pada unit pembangkit untuk mendapatkan daya yang maksimal dengan biaya operasi yang murah.

Untuk menjaga kontinuitas pelayanan kebutuhan energi listrik di daerah Mamuju http://dx.doi.org/10.31963/elekterika.v5i1.2934
Sulawesi Selatan, PT Rekind Daya Mamuju mengoperasikan pembangkit listrik tenaga uap dengan kapasitas pembangkit sebesar 2 x 30 MW. Dalam pengoperasiannya, pembangkit listrik yang digunakan selama ini hanya dioperasikan dengan sistem konvensional. Operasi ekonomis pembangkit dengan menggunakan metode optimasi belum dilaksanakan sehingga biaya operasi yang dibutuhkan masih sangat mahal. Disisi lain kebutuhan energi listrik semakin hari semakin meningkat.

Dalam melakukan optimasi pembangkit, metode economic dispatch (ED) dilakukan untuk melakukan penjadwalan pengoperasian unit pembangkit. Menurut [3, 4] ED adalah sebuah metode yang digunakan untuk meminimalkan biaya operasi unit pembangkit dengan memperhatikan batasan-batasan tehnis dari unit pembangkit tersebut. Tujuan dari ED adalah untuk meminimalkan biaya operasi bahan bakar unit pembangkit [5].

\section{TINJAUAN PUSTAKA}

Dalam mengevaluasi operasi ekonomis pembangkit, karakteristik input dan output pembangkit thermal diperlukan untuk mengidentifikasi besarnya biaya bahan bakar yang dibutuhkan dan daya output yang dihasilkan. Gambar 1 berikut ini menunjukkan hubungan karakteristik input dan output pembangkit thermal.

Dari gambar tersebut menunjukkan bahwa fungsi biaya bahan bakar sangat ditentukan dari besarnya daya output yang dihasilkan oleh 
sebuah unit pembangkit. Dalam operasi system tenaga besarnya daya yang dibangkitkan sama dengan total beban system, seperti yang digambarkan melalui persamaan berikut ini [6]:

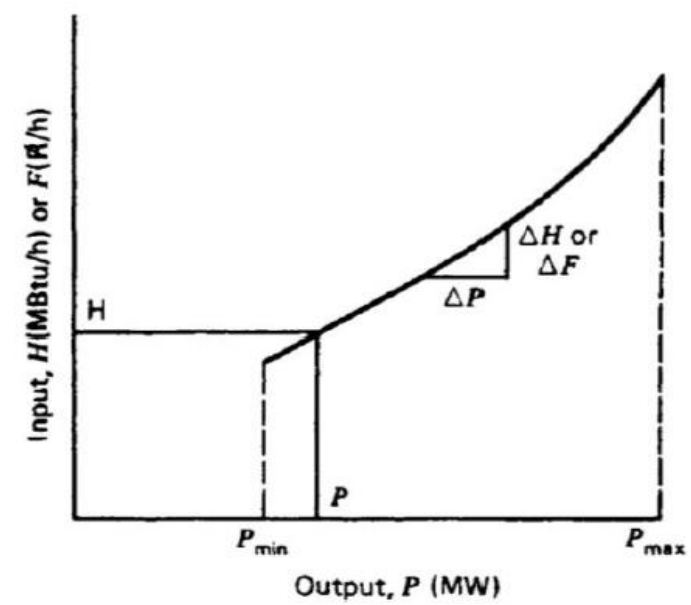

Gambar 1. Karakteristik input dan output pembangkit thermal [2]

$$
\begin{aligned}
& P_{G}=P_{R}+P_{L} \\
& P_{G}=\sum_{i=1}^{n} P_{i}
\end{aligned}
$$

Dimana:

$P_{G}=$ Daya total yang dibangkitkan oleh generator (MW).

$P_{i}=$ Total daya yang dibangkitkan oleh generator ke-i (MW).

$\mathrm{n}$ = Jumlah generator dalam system.

$P_{R}=$ Total beban sistem $(\mathrm{MW})$.

$P_{L}=$ Total rugi - rugi daya nyata saluran transmisi (MW).

Jika pada rugi-rugi transmmisi diabaikan maka jumlah permintaan beban sama dengan jumlah daya yang dibangkitkan seperti yang diuraikan pada persamaan berikut ini:

$$
\sum_{i=1}^{n} P_{i}=P_{R}
$$

Untuk memeroleh biaya pembangkitan yang optimal, maka daya yang dibangkitkan oleh setiap unit harus dihitung berdasarkan biaya bahan bakar masing-masing unit. Persamaan berikut ini menunjukan fungsi konsumsi bahan bakar:

$$
F_{i}\left(P_{i}\right)=\alpha_{i}+\beta_{i} P_{i}+\gamma_{i} P_{i}^{2}
$$

Dengan demikian besarnya total biaya pebangkitan dapat didefinisikan melalui persamaan berikut [7]:
$F_{t}=\sum_{i=1}^{N g} F_{i}\left(P_{i}\right)$

Dimana:

$F_{i} \quad=$ Biaya bahan bakar unit i. (Rp/jam)

$\alpha_{i}, \beta_{i}, \gamma_{i}=$ Koefisien biaya bahan bakar.

$F_{t} \quad=$ Total biaya pembangkitan. (MW)

Perubahan biaya bahan bakar setiap unit dapat dinyatakan dengan persamaan berikut ini [8]:

$$
\frac{\partial F_{t}}{\partial P_{i}}=\lambda+\beta_{i}+2 \gamma_{i} P_{i}
$$

Dalam melakukan analisis maka karakteristik input dan output pembangkit thermal harus diketahui terlebih dahulu. Hubungan antara input bahan bakar (liter/jam) dan output yang dihasilkan oleh pembangkit (MW) dapat diketahui dengan persamaan polynomial tingkat dua, seperti yang dijelaskan berikut ini[9]:

$$
F_{i}\left(P_{i}\right)=\alpha_{i}+\beta_{i} P_{i}+\gamma_{i} P_{i}^{2}
$$

Untuk mengetahui besarnya bahan bakar yang digunakan $\left(C_{n}\right)$ berdasarkan karakteristik masing-masing pembangkit dapat dijelaskan melalui persamaan berikut ini [7]:

$C_{n}(P)_{n}=$ Harga bahan bakar $x F_{n}(P)_{n}(8)$

Sehingga untuk mendapatkan nilai $P_{i}$ diperoleh dengan persmaaan berikut ini [8]:

$$
P_{i}^{(k)}=\frac{\lambda^{(k)}-b_{i}}{2 \alpha_{i}}
$$

Dengan menggunakan metode iterasi maka harga $\lambda$ dapat ditetukan dengan persamaan berikut ini [8]:

$$
\begin{gathered}
\lambda=\frac{P_{R}+\sum_{i}^{n} \frac{b_{i}}{2 \alpha_{i}}}{\sum_{i}^{n} \frac{1}{2 \alpha_{i}}} \\
P_{R}=\sum_{i}^{n} \frac{\lambda-b_{i}}{2 \alpha_{i}}
\end{gathered}
$$

Dengan demikian dapat di tuliskan sebuah fungsi [8]:

$$
\mathrm{f}(\lambda)=P_{R}
$$


Dengan menggunakan persamaan deret Taylor maka dapat dihasilkan [8]:

$$
\Delta \lambda^{(k)}=\frac{\Delta P^{(k)}}{\sum \frac{1}{2 \alpha_{i}}}
$$

Dengan demikian:

$$
\begin{aligned}
& \lambda^{(k+1)}=\lambda^{(k)}+\Delta \lambda^{(k)} \\
& \Delta P^{(k)}=P_{R}-\sum_{i=1}^{n} P_{i}^{(k)}
\end{aligned}
$$

Dengan ketentuan bahwa:

$$
\begin{array}{ll}
\frac{\partial F_{i}}{\partial P_{i}}=\lambda & \text { untuk } P_{i(\min )} \leq P_{i} \leq P_{i(\max )} \\
\frac{\partial F_{i}}{\partial P_{i}} \leq \lambda & \text { untuk } P_{i}=P_{i(\max )} \\
\frac{\partial F_{i}}{\partial P_{i}} \geq \lambda & \text { untuk } P_{i}=P_{i(\min )}
\end{array}
$$

Sebagai komponen utama dalam system ketenagalistrikan pembangkit listrik berfungsi untuk menyiapkan daya yang akan disalurkan melalui jaringan transmisi dan distribusi. Menurut [10] pembangkit listrik sebagai bagian utama dari system ketenagalistrikan mensuplai daya listrik ke rumah pelanggan, industry melalui jaringan transmisi dan distribusi yang terinterkoneksi antara satu dengan yang lainnya. Gambar berikut ini menunjukkan eksistensi pembangkit listrik sebagai suatu kesatuan yang utuh dalam system kenetanalistrikan dalam menyalurkan energi listrik ke konsumen.

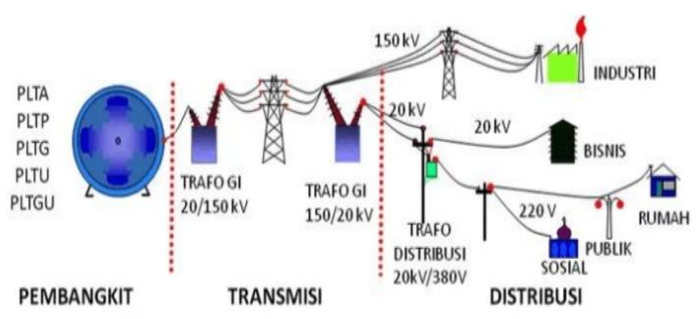

Gambar 1. Diagran system tenaga listrik [11]

Untuk enjaga system penyaluran listrik secara kontinuitas maka system evaluasi keandalan pada system pembangit perlu dilakukan. Hal ini disebabkan karena berhubungan dengan biaya yang digunakan dalam mengoperasikan system pembangkit tersebut. Disamping itu juga kebutuhan daya listrik yang semakin hari semakin bertambah. Menurut [12] kebutuhan energi listrik semakin hari semakin pesat disebabkan karena peningkatan jumlah penduduk sehingga memerlukan biaya operasional pembangkit listrik yang besar.

Untuk mengantisipasi hal ini maka beberapa peneliti telah melakukan penelitian sebelumnya, diantaranya: penggunaan metode iterasi lambda untuk operasi ekonomis pembangkit dengan menggunakan komputasi parallel [6]. Tujuan dari peneltian ini adalah untuk melakukan penjadwalan pada masingmasing unit pembangkit sehingga diperolah daya keluaran yang optimal dengan biaya yang rlatif murah. Penelitian dilakukan pada system IEEE 30 bus dan system $500 \mathrm{kV}$ Jawa-Bali. Dari hasil penelitian menunjukkan bahwa biaya bahan bakar minimum terdapat pada kombinasi 1-1-1-1-1-1 dengan nilai bahan bakar sebesar \$767.6023/Jam. Sedangkan untuk system $500 \mathrm{kV}$ Jawa-Bali diperoleh nilai bahan bakar yang bervariasi pada setiap jam. Biaya operasi yang paling minimum adalah sebesar Rp1.549.600.000/Jam yang beroperasi pada jam 24.30 - 1.29 WIB.

Metode practical swam optimization (PSO) digunakan untuk mencari biaya operasi ekonomis pembangkit listrik turbin gas PLTG Grati [13]. Peneltian ini dilakukan untuk menghitung penghematan biaya bahan bakar gas berdasarkan nilai heat rate khususnya pada perhitungan biaya pokok produksi. Dari hasil penelitian menunjukkan bahwa penghematan bisa dilakukan dengan membandingkan antara penggunaan metode PSO dengan kondisi aktual. Dari hasil penelitian menunjukkan bahwa besarnya penghematan konsumsi gas sebesar 0.5968 BBTU/h atau jika dikonversi kedalam $\operatorname{Rp} 57.168,00 / \mathrm{h}$ untuk total permintaan daya $310 \mathrm{MW}$.

Metode lain yang telah digunakan adalah metode equal incremental cost. Seperti halnya dengan penelitian sebelumnya metode ini juga digunakan untuk mencari nilai bahan bakar yang minimum dalam mengoperasikan pembangkit thermal untuk memenuhi permintaan daya konsumen. Penelitian ini dilakukan untuk mencari biaya bahan bakar optimal 2 unit pembangkit di PLTU Pangkalan Susu. Dari hasil penelitian menunjukkan bahwa 
besarnya biaya minimum bahan bakar adalah sebesar 13,111 \$/hour [14].

\section{METODE PENELITIAN}

Berikut ini dijelaskan diagram alir penelitian metode iterasi lamda untuk menentukan besarnya biaya bahan bakar untuk mendapatkan daya yang optimal.

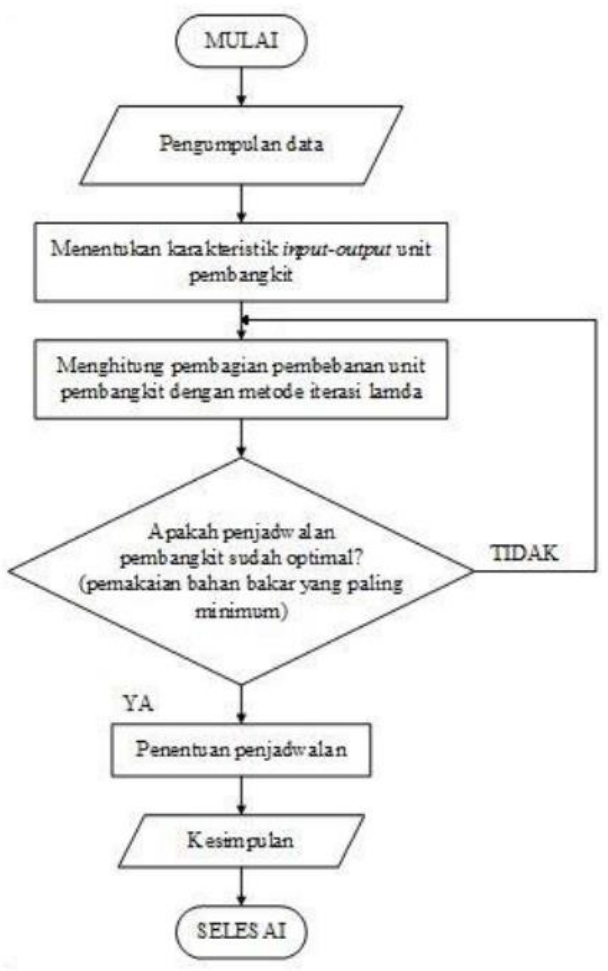

Gambar 2. Diagran Alir Penelitian

\section{HASIL DAN PEMBAHASAN}

Dalam menyiplai kebutuhan beban listrik konsumen di daerah Kabupaten mamuju, PT Rekind Daya Mamuju memiliki Pembangkit Listrik Tenaga Uap (PLTU) dengan kapasitas 2x30 MW untuk unit pembangkit I dan II. Pada penelitian beban pada hari Ahad, 21 Febaruari 2021 diambil sebagai contoh analisa data. Tabel berikut ini menunjukkan data input dan output pada setiap unit generator pembangkit:

Tabel I. Daya dan bahan Bakar unit 1 dan 2

\begin{tabular}{ccccc}
\hline Waktu & \multicolumn{2}{c}{ Unit 1 } & \multicolumn{2}{c}{ Unit 2 } \\
& Daya & $\begin{array}{c}\text { Bahan } \\
\text { Bakar } \\
\text { Tah/Jam }\end{array}$ & Daya & $\begin{array}{c}\text { MW } \\
\text { Bakar } \\
\text { Ton/Jam }\end{array}$ \\
\hline 00:00 & 25.565 & 23.64 & 27.593 & 26 \\
$01: 00$ & 16.297 & 14.649 & 20.702 & 26 \\
$02: 00$ & 12.379 & 16.563 & 14.149 & 14 \\
$03: 00$ & 12.909 & 16.601 & 14.637 & 15 \\
$04: 00$ & 12.832 & 15.328 & 14.267 & 16.004 \\
\hline
\end{tabular}

http://dx.doi.org/10.31963/elekterika.v5i1.2934

\begin{tabular}{ccccc}
\hline $05: 00$ & 12.567 & 15.375 & 14.432 & 15.988 \\
$06: 00$ & 12.917 & 16.671 & 14.354 & 15.008 \\
$07: 00$ & 12.766 & 16.375 & 14.68 & 15 \\
$08: 00$ & 12.747 & 16.555 & 14.675 & 15 \\
$09: 00$ & 12.729 & 16.947 & 14.435 & 15 \\
$10: 00$ & 15.366 & 21.281 & 16.78 & 15 \\
$11: 00$ & 20.311 & 22.469 & 22.201 & 22 \\
$12: 00$ & 25.202 & 26.61 & 26.9 & 23 \\
$13: 00$ & 25.381 & 23.078 & 27.263 & 27 \\
$14: 00$ & 25.348 & 21.961 & 26.889 & 28 \\
$15: 00$ & 25.204 & 21.961 & 26.965 & 28 \\
$16: 00$ & 25.235 & 27.242 & 26.929 & 22 \\
$17: 00$ & 25.047 & 24.993 & 27.154 & 25 \\
$18: 00$ & 19.701 & 24.445 & 22.336 & 20 \\
$19: 00$ & 19.986 & 23.438 & 22.031 & 21.007 \\
$20: 00$ & 20.354 & 24.242 & 22.345 & 21.004 \\
$21: 00$ & 19.825 & 21.281 & 22.207 & 24 \\
$22: 00$ & 20.241 & 24.993 & 22.375 & 19.875 \\
$23: 00$ & 20.093 & 23.672 & 22.378 & 21 \\
\hline & & & &
\end{tabular}

4.1 Fungsi Karakteristik input dan output pembangkit

Persamaan (7) diatas digunakan untuk mendapatkan fungsi karakteristik input dan output pembangkit seperti yang dijelaskan melalui Tabel II berikut ini:

Tabel II. Fungsi karakteristik pembangkit

\begin{tabular}{cc}
\hline Unit & Fungsi Karakteristik \\
\hline Unit 1 & $-0.882+1.666 \mathrm{P}_{1}-0.025 \mathrm{P}_{1}^{2}$ \\
\hline Unit 2 & $-9.747+2.209 \mathrm{P}_{2}-0.036 \mathrm{P}_{2}^{2}$ \\
\hline
\end{tabular}

\subsection{Fungsi biaya bahan bakar}

Fungsi biaya bahan bakar diperoleh dari hasil perkalian antara daya terhadap bahan bakar. Bahan bakar yang digunakan di PLTU Mamuju adalah batubara. Harga Jual batu bara untuk penyediaan tenaga listrik untuk kepentingan umum telah ditetapkan sebesar Rp 487,800,00 per ton.

Berdasarkan persamaan (8) maka fungsi bahan bakar dapat ditentukan seperti yang dijelaskan melalui Tabel III berikut ini:

Tabel III. Fungsi biaya bahan bakar

\begin{tabular}{cl}
\hline Unit & \multicolumn{1}{c}{ Fungsi bahan bakar } \\
\hline Unit 1 & $430239.6+812674.8 \mathrm{P}_{1}-$ \\
& $12195 \mathrm{P}_{1}{ }^{2}$ \\
\hline Unit 2 & $-4754586.6+1077550.2 \mathrm{P}_{2}-$ \\
& $17560.8 \mathrm{P}_{2}{ }^{2}$ \\
\hline
\end{tabular}




\subsection{Optimasi biaya bahan bakar}

Optimasi biaya bahan bakar pembangkit dapat dilakukan dengan mencari biaya operasi terendah yang didapatkan dari hubungan antara fungsi biaya bahan bakar pembangkit dan daya yang dibangkitkan dari tiap unit pembangkit.

Dengan menggunakan persamaan (1) sampai (17), maka besarnya biaya pembangkitan dengan menggunakan metode iterasi lamda diejalskan melalui Tabel berikut ini:

Tabel II. Hasil optimasi biaya bahan bakar

\begin{tabular}{|c|c|c|c|}
\hline \multirow[t]{2}{*}{ Waktu } & $\begin{array}{l}\text { Sebelum } \\
\text { optimasi }\end{array}$ & $\begin{array}{l}\text { Sesudah } \\
\text { optimasi }\end{array}$ & Selisih \\
\hline & Rp/Jam & Rp/Jam & Rp/Jam \\
\hline 00:00 & $24,214,392.00$ & $24,038,162.98$ & $176,229.02$ \\
\hline 01:00 & $19,828,582.20$ & $19,637,001.93$ & $191,580.27$ \\
\hline 02:00 & $14,908,631.40$ & $14,778,213.45$ & $130,417.95$ \\
\hline 03:00 & $15,414,967.80$ & $15,319,847.53$ & $95,120.27$ \\
\hline 04:00 & $15,283,749.60$ & $15,083,854.98$ & $199,894.62$ \\
\hline 05:00 & $15,298,871.40$ & $15,030,666.55$ & $268,204.85$ \\
\hline 06:00 & $15,453,016.20$ & $15,175,002.38$ & $278,013.82$ \\
\hline 07:00 & $15,304,725.00$ & $15,267,302.52$ & $37,422.48$ \\
\hline 08:00 & $15,392,529.00$ & $15,254,670.29$ & $137,858.71$ \\
\hline 09:00 & $15,583,746.60$ & $15,118,350.28$ & $465,396.32$ \\
\hline 10:00 & $17,697,871.80$ & $17,581,318.08$ & $116,553.72$ \\
\hline 11:00 & $21,691,978.20$ & $21,560,960.18$ & $131,018.02$ \\
\hline $12: 00$ & $24,199,758.00$ & $23,865,328.62$ & $334,429.38$ \\
\hline 13:00 & $24,428,048.40$ & $23,956,042.18$ & $472,006.22$ \\
\hline $14: 00$ & $24,370,975.80$ & $23,888,318.77$ & $482,657.03$ \\
\hline 15:00 & $24,370,975.80$ & $23,876,771.34$ & $494,204.46$ \\
\hline 16:00 & $24,020,247.60$ & $23,875,919.64$ & $144,327.96$ \\
\hline 17:00 & $24,386,585.40$ & $23,882,213.72$ & $504,371.68$ \\
\hline 18:00 & $21,680,271.00$ & $21,412,414.86$ & $267,856.14$ \\
\hline 19:00 & $21,680,271.00$ & $21,406,089.07$ & $274,181.93$ \\
\hline 20:00 & $22,070,998.80$ & $21,618,549.17$ & $452,449.63$ \\
\hline 21:00 & $22,088,071.80$ & $21,410,833.95$ & $677,237.85$ \\
\hline $22: 00$ & $21,886,610.40$ & $21,593,050.41$ & $293,559.99$ \\
\hline 23:00 & $21,791,001.60$ & $21,548,266.44$ & $242,735.16$ \\
\hline Total & $483,046,876.80$ & 476179149.3 & $6,867,727.49$ \\
\hline
\end{tabular}

Berdasarkan Tabel 7 diatas menunjukkan bahwa besarnya biaya yang dibutuhkan untuk setiap jam berubah-ubah berdasarkan dari kebutuhan daya listrik. Besarnya biaya sebelum dilakukan optimasi berbeda dengan besarnya biaya setelah dilakukan optimasi. Hal ini disebabkan karena perbedaan karakterisitk input dan ouput masing-masing pembangkit sehingga penjadwalan pengoperasian dapat diatur untuk menghasilkan nilai bahan bakar yang minimum. Dengan demikian penghematan biaya dapat tercapai setelah melakukan optimasi.

Gambar berikut ini menunjukkan perbandingan biaya bahan bakar untuk masing- masing pembangkit sebelum dan setelah optimasi.

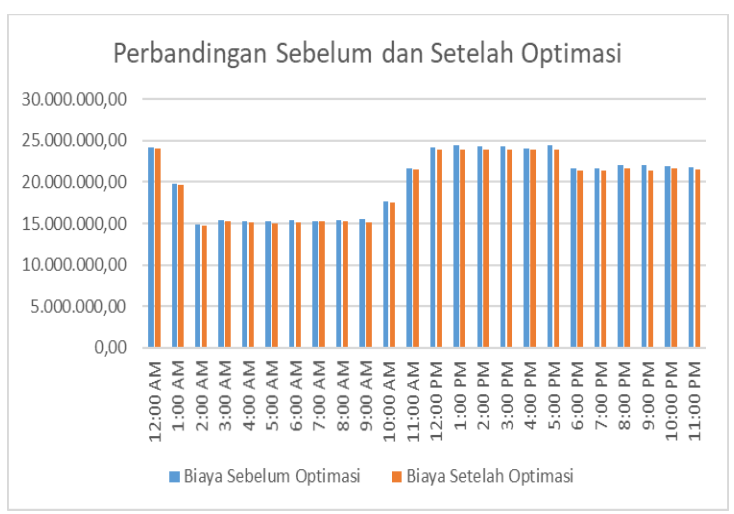

Gambar 3. Hasil perbandingan sebelum dan sesudah optimasi

Berdasarkan Gambar diatas menunjukkan bahwa biaya bahan bakar tertinggi antara jam 12.00 - 05.00 PM. Hal ini disebabkan karena beban puncak yang terjadi pada rentang waktu tersebut. Besarnya biaya bahan bakar tertinggi sebesar Rp 24,428,048.40 terjadi pada jam 13.00. Setelah dilakukan optimasi maka besar biaya bahan bakar dapat diminimalisir sampai dengan Rp 23,956,042.18. Dengan demikian dapat dilakukan penghematan sebesar $\mathrm{Rp}$ 472,006.22.

Sebaliknya biaya bahan bakar terendah antara jam 14.00 - 09.00. Hal ini disebabkan karena penggunaan daya listrik pada rentang waktu tersebut menurun. Sebagian konsumen tidak melakukan aktifitas pada malam hari dan pagi hari. Pada rentang waktu tersebut, besarnya biaya bahan bakar terendah adalah $\mathrm{Rp}$ 14,908,631.40 terjadi pada saat pembangkit dioperasikan pada jam 02.00. Setelah dilakukan optimasi maka biaya bahan bakar dapat diturunkan menjadi Rp 14,778,213.45. sehingga dapat dilakukan penghematan biaya bahan bakar sebesar Rp 130,417.95.

\section{KESIMPULAN}

Berdasarkan hasil penelitian menunjukkan bahwa metode iteasi lambda dapat digunakan untuk meminimalkan biaya operasional pembangkit. Pada penelitian ini besarnya biaya operasional pembangkit berubah-ubah setiap jam sesuai dengan kebutuhan daya konsumen. Besarnya biaya operasi bahan bakar sebelum optimasi Rp. 483,046,876.80. Besarnya biaya bahan bakar setelah optimasi sebesar Rp. 476179149.3. Dengan demikian besarnya 
penghemtan biaya yang diperoleh setelah menerapkan metode ini adalah Rp $6,867,727.49$.

\section{REFERENSI}

1. Delima and Syafii, Operasi ekonomis dan unit commitment pembangkit thermal pada sistem kelistrikan Jambi. Jurnal Nasional Teknik Elektro, 2016. 5: p. 368375.

2. Riswandi, S., R.S. Lubis, and M. Syukri, Operasi Ekonomis pada Sistem Pembangkit Thermal Sumatera Barat dengan Menggunakan Metode Iterasi Lambda. Jurnal Komputer, Informasi Teknologi, dan Elektro, 2021. 6: p. 19-25.

3. Maydilasari, M.P., E.A. Zuliari, and T. Wati. Economic Emission Dispatch Mempertimbangkan Valve-Point Effect Menggunakan Particle Swarm Optimization (PSO). in Seminar Nasional Sains dan Teknologi Terapan VIII. 2020. Surabaya: Institut Teknologi Adhi Tama Surabaya.

4. L.Dong, et al., An adaptive decentralized economic dispatch method for virtual power plant. Applied Energy, 2021. 300: p. 117347.

5. Talbi, E.H., et al. Solution of Economic and Environmental Power Dispatch Problem of an Electrical Power System using BFGS-AL Algorithm. in International Workshop on the Advancements Model Driven Engineering. 2020. Warsaw Poland.

6. Wijono, D. Kristianto, and H. Suyono, Operasi Ekonomis Pembangkit Tenaga Listrik Dengan Metode Iterasi Lambda Menggunakan Komputasi Paralel. Jurnal Mahasiswa Teknik Elektro Universitas Brawijaya, 2014. 2(6): p. 1-6.

7. H.Nabila, Analisis Economic Dispatch Pada PLTU Sektor Bukit Asam Menggunalan Metode Iterasi Lambda Dan Dynamic Programming, in JJurusan Teknik Elektro. 2017, Universitas Lampung. p. 5-10.

8. H.Saadat, Power system analysis. Vol. 2. 1999: McGraw-Hill.

9. W.F.Galla, N.Nursalim, and E.Mauboy, Penjadwalan Optimum Pembangkit Thermal Menggunakan Metode Iterasi Lambda Studi Kasus Pada Pembangkit
Listrik Tenaga Uap Bolok. Media Elektro, 2019. 8: p. 140-148.

10. Qazi, S., Standalone Photovoltaic (PV) Systems for Disaster Relief and Remote Areas. Vol. 1. 2016: Elsevier.

11. Febriana, R. Pembagian Sistem Penyaluran Tenaga Listrik. 2020 [cited 202117 Februari]; Available from: https://www.warriornux.com/pembagiansistem-penyaluran-tenaga-listrik/.

12. Rajagukguk, A.S.F., M. Pakiding, and M. Rumbayan, Kajian Perencanaan Kebutuhan dan Pemenuhan Energi Listrik di Kota Manado. E-journal Teknik Elektro dan Komputer, 2015. 1: p. 1-12.

13. Wahyudi, M.F., S. Setyawidaya, and Fachrudin, Metode Particle Swarm Optimization Untuk Menentukan Daya Optimal Turbin Gas PLTGU Grati Berdasarkan Heat Rate. Journal of Application and Science on Electrical Engineering, 2021. 2: p. 37-46.

14. Hasibuan, A., et al., Economic Dispatch Analysis Using Equal Incremental Cost Method with Linear Regression Approach. Journal of Renewable Energy, Electrical, and Computer Engineering, 2021. 1: p. 1622. 